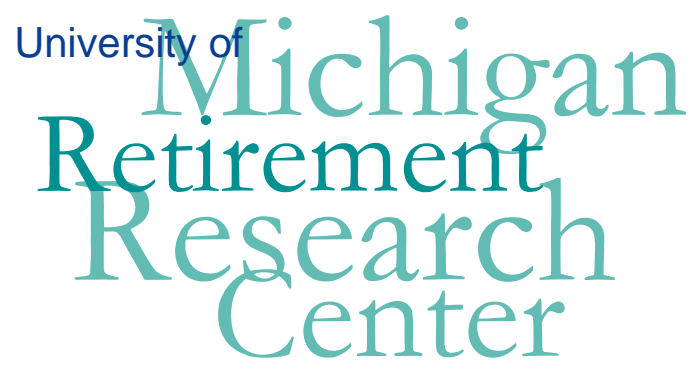

Working Paper

WP 2009-206

How Do Pension Changes Affect Retirement Preparedness?

The Trend to Defined Contribution Plans and the Vulnerability of the Retirement Age Population to the Stock Market Decline of 2008-2009

\author{
Alan L. Gustman, Thomas L. Steinmeier and Nahid Tabatabai
}

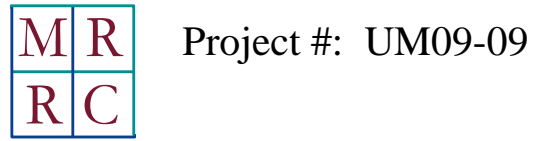





\title{
How Do Pension Changes Affect Retirement Preparedness? The Trend to Defined Contribution Plans and the Vulnerability of the Retirement Age Population to the Stock Market Decline of 2008-2009
}

\author{
Alan L. Gustman \\ Dartmouth College and NBER \\ Thomas L. Steinmeier \\ Texas Tech University \\ Nahid Tabatabai \\ Dartmouth College \\ October 2009 \\ Michigan Retirement Research Center \\ University of Michigan \\ P.O. Box 1248 \\ Ann Arbor, MI 48104 \\ http://www.mrrc.isr.umich.edu/ \\ (734) 615-0422
}

\section{Acknowledgements}

This work was supported by a grant from the Social Security Administration through the Michigan Retirement Research Center (Grant \# 10-M-98362-5-01). The findings and conclusions expressed are solely those of the author and do not represent the views of the Social Security Administration, any agency of the Federal government, or the Michigan Retirement Research Center.

Regents of the University of Michigan

Julia Donovan Darrow, Ann Arbor; Laurence B. Deitch, Bingham Farms; Denise Ilitch, Bingham Farms; Olivia P. Maynard, Goodrich; Andrea Fischer Newman, Ann Arbor; Andrew C. Richner, Grosse Pointe Park; S. Martin Taylor, Gross Pointe Farms; Katherine E. White, Ann Arbor; Mary Sue Coleman, ex officio 


\title{
How Do Pension Changes Affect Retirement Preparedness? The Trend to Defined Contribution Plans and the Vulnerability of the Retirement Age Population to the Stock Market Decline of 2008-2009
}

\begin{abstract}
Our findings suggest that although the consequences of the decline in the stock market are serious for those approaching their retirement, the average person approaching retirement age is not likely to suffer a life changing financial loss from the stock market downturn of 2008-2009. Similarly, the likely effects of the stock market downturn on retirements have been greatly exaggerated. If there is any postponement of retirement due to stock market losses, on average it will be a matter of a few months rather than years. Counting layoffs, retirements may be accelerated rather than reduced. We provide background information that corrects misperceptions about pension holdings of the retirement age population. Pension coverage is much more extensive than is usually recognized. Over three quarters of the households with a person ages 51 to 56 in 2004 are currently covered by a pension, or have enjoyed pension coverage in the past. Pension wealth accounts for 23 percent of the total wealth of those on the cusp of retirement. For those nearing retirement age, defined contribution plans remain immature. As a result, almost two thirds of pension wealth held by those 51 to 56 in 2004 is in the form of a defined benefit plan. Lastly, women approaching retirement age are more likely to be covered by a pension than are women from earlier cohorts and they account for a significantly larger share of household pension wealth.
\end{abstract}

\section{Authors' Acknowledgements}

Part 1 of this paper provides background information on pension trends drawn from our forthcoming book, Pensions in the Health and Retirement Study, Harvard University Press, which has benefitted from support by NIA grants IPOIAG022481, R01 AG024337, R01 AG022956, and from subcontracts from the Health and Retirement Study to Dartmouth College (U01AG09740). The research paper in Part 2, "What the Stock Market Decline Means for the Financial Security and Retirement Choices of the Near-Retirement Population", has been supported by the Social Security Administration through the Michigan Retirement Research Center under grant number UM09-09. We are grateful to Kandice Kapinos and her colleagues at the Health and Retirement Study who provided us with data estimating Social Security wealth and to Kapinos for her advice on the data. Howard Iams, Bruce Sacerdote, Andrew Samwick, Steve Venti and participants at the NBER Summer Institute and RRC summer meetings provided many useful comments. 


\title{
How Do Pension Changes Affect Retirement Preparedness? The Trend to Defined Contribution Plans and the Vulnerability of the Retirement Age Population to the Stock Market Decline of 2008-2009
}

\author{
Alan L. Gustman, Thomas L. Steinmeier and Nahid Tabatabai
}

This document has two parts. The first part presents background information on trends in pensions drawn from our forthcoming book, Pensions in the Health and Retirement Study. Using data from the Health and Retirement Study (HRS), trends in pensions are described among three cohorts: those aged 51 to 56 in 1992, called the HRS cohort; those 51 to 56 in 1998, called the war baby cohort; and those 51 to 56 in 2004, called the early boomer cohort. The second part is a paper which deals with the likely effects of the stock market decline on those approaching retirement age.

The background data show that pension coverage is much more extensive than is usually recognized. Coverage of those approaching retirement age comes not only from plans on current jobs, but also from pensions held from previous employment. In the most expansive definition of coverage, if pension coverage is measured at the household level, so that individuals whose spouse is covered by a pension are also said to be covered, over three quarters of the households with a person ages 51 to 56 in 2004 are currently covered by a pension, or have enjoyed pension coverage in the past. This is in contrast to the usual measure of coverage - typically reporting that 50 or 60 percent of current employees are covered by a pension.

Second, the background data also show that pension wealth accounts for 23 percent of the total wealth of the early boomer households.

Third, the trend to defined contribution plans is readily apparent in the HRS data. However, detailed data on job and pension tenure by plan type also show that defined 
contribution plans remain immature. As a result, almost two thirds of total pension wealth held by households with at least one member 51 to 56 in 2006 is in the form of a defined benefit plan.

Fourth, reflecting major changes in the level and continuity of their labor force participation, women from the early boomer cohort are more likely to be covered by a pension than are women from earlier cohorts, and their pensions are more valuable than the plans held by women in the original HRS cohort.

Pension trends, in turn, play an important role in determining how the stock market decline of 2008-2009 affects those who are approaching retirement. The second part of our analysis, contained in a paper entitled "What the Stock Market Decline Means for the Financial Security and Retirement Choices of the Near-Retirement Population”, deals with that issue.

That paper focuses on the early boomer cohort, those 51 to 56 in 2004, the group closest to retirement as the recession unfolded. We find those nearing retirement had only limited exposure to the stock market decline. As noted, their pensions accounted for 23 percent of their total household wealth. However, because defined contribution plans remain immature for those approaching retirement age, 35 percent of their pension wealth is in the form of a defined contribution plan. In addition, 62 percent of their DC pension wealth from current plans is held in the form of stocks. When direct stock holdings, and stock holdings in IRAs, are added to stock holdings in DC plans, in 2006 total stock holdings of the early boomer cohort averaged 15.2 percent of total wealth. This greatly limits the direct exposure of the early boomer population to the decline in the stock market, in that a one third decline in stock prices would reduce household wealth by about 5 percent. We also show that as a result, despite speculation to the contrary, those approaching retirement are not likely to substantially delay their retirement in reaction to the stock market decline, probably postponing their retirement by no more than a couple of 
months. Similarly, we show that those approaching retirement are not likely to be greatly or immediately affected by the decline in housing prices.

The greatest worry is for those who lose their jobs, or are exposed to multiple hazards brought about by the recession. The HRS does not yet have evidence on the effects of layoffs on retirement. We note, however, that the effects of job loss on retirement are ambiguous, and might even result in earlier rather than later retirements. We turn now to the first of the two parts of our analysis.

\section{Pension Trends in the Health and Retirement Study ${ }^{2}$}

Here we review some key pension trends among cohorts of those ages 51 to 56 in 1992, 1998 and 2004 from the Health and Retirement Study. Evidence is presented regarding trends in pension coverage, plan type, plan values, and the share of total wealth accounted for by pensions and Social Security.

\section{A. Trends in Pension Coverage}

Table 1 shows pension coverage rates for 51 to 56 year old HRS respondents classified by pension status, by cohort. The categories defining pension status include whether the pension is from a current job, from a previous job and yet to enter pay status (dormant), is currently paying benefits (in pay status), is "live”, defined as falling in any of the previous categories, and whether the respondent was at one time covered by a pension that is no longer live. It may have been cashed out, rolled over, or disposed of in some other way. From column1, row 4 of Table 1, in 1992, 52.7 percent of HRS age eligible respondents were participating in at least one live

\footnotetext{
${ }^{2}$ The material in this section is drawn from our forthcoming book, Pensions in the Health and Retirement Study, Harvard University Press. We are grateful for support from NIA grants "Economic and Health Determinants of Retirement Behavior," IPOIAG022481, "Behavioral Analysis In Structural Retirement Models” R01 AG024337, "Integrating Retirement Models” R01 AG022956, and from subcontracts from the Health and Retirement Study to Dartmouth College (U01AG09740).
} 
pension plan. Among those 51 to 56 years old in 2004, 68 percent of respondents report ever having a pension. Note that the crude rule of thumb for all employees is that about half have a pension, with about 60 percent of older employees having a pension on their current job. The higher coverage rate among all respondents in HRS data is due both to the fact that pensions are aggregated over current and past jobs, including pensions that were cashed out, rolled over, or otherwise disposed of when the respondent left a previous job.

Table 1: Percent of Respondents Ages 51 to 56 with Any/Dormant/Live Pension from Current/Last or Previous Jobs by Cohort: Weighted

\begin{tabular}{|l|c|c|c|}
\hline Pension Status & HRS 1992 & War Baby 1998 & $\begin{array}{c}\text { Early Boomer } \\
2004\end{array}$ \\
\hline \hline Current pension & 43.0 & 46.2 & 46.8 \\
\hline Dormant pension & 10.3 & 13.6 & 15.9 \\
\hline Pension in pay status & 5.0 & 5.0 & 3.5 \\
\hline Live pension & 52.7 & 56.9 & 56.6 \\
\hline Ever held a pension & 62.4 & 68.7 & 68.0 \\
\hline
\end{tabular}

Source: Gustman, Steinmeier and Tabatabai (forthcoming), Table 5.11. Live pensions include any pensions on current jobs, dormant pensions, and pensions in pay status. 
Table 2: Percent of Households and Respondents With Any Own/Spouse/Partner Pension from Current/Last or Previous Jobs by Cohorts: Ages 51-56 in 1992, 1998, and 2004- Weighted

\begin{tabular}{|l|c|c|c||}
\hline Household Members & HRS & War Babies & Early Boomers \\
\hline All Respondents & 78.8 & 81.2 & 80.4 \\
All Households & 76.9 & 79.3 & 78.6 \\
$\quad$ Couples & 83.9 & 87.1 & 76.4 \\
$\quad$ Males & 74.8 & 57.7 & 74.4 \\
$\quad$ Females & 49.2 & 62.1 & 62.5 \\
Singles & 58.8 & 62.8 & 59.2 \\
$\quad$ Males & 64.8 & 61.6 & 61.1 \\
Females & 55.1 & 2662 & 2770 \\
\hline
\end{tabular}

Source: Gustman, Steinmeier and Tabatabai (forthcoming), Table 5.12. Note: Married respondents whose spouses were not interviewed are included in the couples' category. 


\section{Coverage Through a Spouse}

Many couples have only one spouse working, or at least only one spouse with a prolonged history of labor market activity. It seems unreasonable to judge pension coverage for members of these households by focusing separately on each individual. Accordingly, in addition to own coverage, Table 2 reports a respondent as being covered or having been covered by a pension not only if the respondent was covered in his or her own right, but also if that respondent's spouse is or was covered.

By 2004, using that definition of coverage, over four fifths of HRS respondents in the early boomer cohort were covered or are covered by a pension. Over 78 percent of households were or are covered. Among couple households, again by 2004, 74.4 percent of the coverage comes from the man; 62.5 percent of women are covered based on their own work. By 2004, the difference in coverage between single men and single women, that is, the difference between 61.1 percent for single men and 58.0 percent for single women, is much smaller than the gap between men and women in couple households. In both couple households and in single households, the gap in coverage between men and women has narrowed substantially over the 1992 to 2004 period.

\section{B. Plan Type}

The strong trend toward defined contribution plans among younger cohorts is easily seen by comparing values across the columns for any of the rows in Table 3. The columns report outcomes at ages 51 to 56, in the year each cohort entered the HRS. Members of the original HRS cohort entered the survey in 1992; those from the war baby cohort entered in 1998; and finally members of the early boomer cohort entered in $2004 .{ }^{3}$ For example, the percentage with a DB plan only declines from $41 \%$ to $25 \%$ between the oldest and youngest cohorts, while the percent with a DC plan only increases from $30 \%$ to $46 \%$.

\footnotetext{
${ }^{3}$ Members from younger cohorts with an older spouse may have entered the survey before they reached age 51. Our estimates carry forward and adjust values of pensions and Social Security for these younger spouses, including them with the majority of the members of their cohort who entered the HRS when they were 51 to 56 years old.
} 
Despite the differences in plan type recorded by members of different cohorts, it is clear from the data in Table 3 that the transition to DC plans remains incomplete. Thus in row 4, column 3, among full time employees, as of 2004, 51 percent of the members of the Early Boomer cohort with a pension has at least one defined benefit plan.

Table 4 indicates the incomplete status of the transition to DC plans by comparing tenure on the job with tenure under the pension plan. There is a considerable gap between job tenure and pension tenure for those with a DC plan. There is very little gap for those with a DB plan. Most importantly, tenure under DC plans averages less than ten years, while tenure under DB plans averages over sixteen years. One reason for the immaturity of the DC plans is that the predominant form of the DC pension, the 401k plan, was not available in its current form until around 1982. It took a considerable amount of time for this innovation to spread. Thus the spread of the $401 \mathrm{k}$ plan lasted through the $1990 \mathrm{~s}$ and past the turn of the century. In addition, the jobs held by members of HRS cohorts analyzed here, born in the 1930s and 1940s, are more likely to be in manufacturing and other old line industries, and in jobs covered by unions, where the $401 \mathrm{k}$ innovation spread even more slowly, if at all. 
Table 3: Pension Plan Type Among Full Time Employees Ages 51 to 56 with a Pension: Weighted

\begin{tabular}{|l|c|c|c||}
\hline Pension Characteristics & 1992 HRS & 1998 Warbabies & $\begin{array}{c}\text { 2004 Early } \\
\text { Boomers }\end{array}$ \\
\hline \hline \% with DB Plan Only & 41 & 29 & 25 \\
\hline \% with DC Plan Only & 30 & 38 & 26 \\
\hline \% with Combination/Both Plans & 28 & 32 & 51 \\
\hline \% with at Least One DB Plan & 69 & 70 & 72 \\
\hline $\begin{array}{l}\text { \% with at Least One DC plan } \\
\text { \% Who Respond Don't }\end{array}$ & 2 & 1 & 3 \\
\hline \hline
\end{tabular}

Source: Gustman, Steinmeier and Tabatabai (forthcoming), Tables 6.2 and 6.3. 
Table 4: Average Number of Years of Job Tenure and Pension Tenure by Plan Type and Cohort Ages 51 to 56 in 1992,1998 and 2004: weighted

\begin{tabular}{|c|c|c|c|c||}
\hline \multirow{2}{*}{ Cohorts } & \multicolumn{2}{|c|}{ DB Plans } & \multicolumn{2}{c|}{ DC Plans } \\
\cline { 2 - 5 } & Job Tenure & Pension Tenure & Job Tenure & 15.6 \\
\hline HRS & 17.6 & 16.4 & $(1197)$ & $(1197)$ \\
\hline War Babies & $(1540)$ & $(1540)$ & 14.2 & $(6.4$ \\
\hline Early Boomers & 18.5 & 17.4 & $(629)$ & $(629)$ \\
\hline
\end{tabular}

Source: Gustman, Steinmeier and Tabatabai (forthcoming), Table 6.4. 


\section{Plan Value}

The slow pace of the transition from DB to DC plans means that a substantial fraction of those in the youngest HRS cohort is still covered by a DB plan. In addition, those who are covered by a DC plan have not been covered for their full work life. Because their plans remain immature, they are worth less that they would have been were those with DC plans covered over the full period of their employment tenure.

Table 5 cumulates pension wealth from current and previous jobs, and aggregates pension wealth by household. The four columns in the table report total pension wealth, total pension wealth due to DB plans, total pension wealth due to DC plans, and the share of the household's total pension wealth that is accounted for by a DC plan. As seen from row 3, column 4, 37 percent of the pension wealth owned by households with at least one person 51 to 56 in 2004 is in a defined contribution plan. 
Table 5: Observed Plus Imputed Pension Values From Current, Past and Previous Jobs Per Household, by Source of Pension by Plan Type, 1992, 1998, and 2004 (in 1992 Dollars)- Respondent Data: Weighted

\begin{tabular}{|c|c|c|c|c||}
\hline Cohorts & Total HH Pension & Total Pension Due to DBs & $\begin{array}{c}\text { Total Pension Due to } \\
\text { DCs }\end{array}$ & $\begin{array}{c}\text { \% of Total HH } \\
\text { Pension Due to DCs }\end{array}$ \\
\hline HRS: $51-56$ & $\begin{array}{c}149,753 \\
(3003)\end{array}$ & 112,480 & 37,274 & $25 \%$ \\
\hline WBs: $51-56$ & $\begin{array}{c}158,432 \\
(1758)\end{array}$ & 103,230 & 55,202 & $35 \%$ \\
\hline EBs: $51-56$ & $\begin{array}{c}161,490 \\
(1709)\end{array}$ & 101,095 & 60,399 & $37 \%$ \\
\hline
\end{tabular}

Source: Gustman, Steinmeier and Tabatabai (forthcoming), Table 9.19. 
Table 6: Observed Plus Imputed Pension Values From Current, Past and Previous Jobs Per Household, by Source of Pension by Gender, 1992, 1998, and 2004 (in 1992 Dollars)- Respondent Data: Weighted

\begin{tabular}{|c|c|c|c|c|}
\hline Cohorts & Total HH Pension Wealth & $\begin{array}{c}\text { Total Pension Wealth Due } \\
\text { to Men }\end{array}$ & $\begin{array}{c}\text { Total Pension Wealth } \\
\text { Due to Women }\end{array}$ & $\begin{array}{c}\text { Pension Wotal HH } \\
\text { to Women Due }\end{array}$ \\
\hline HRS: $51-56$ & $\begin{array}{c}149,753 \\
(3003)\end{array}$ & 118,560 & 31,194 \\
\hline WBs: $51-56$ & $\begin{array}{c}158,432 \\
(1758)\end{array}$ & 114,997 & 43,435 & $27 \%$ \\
\hline EBs: $51-56$ & $\begin{array}{c}161,494 \\
(1709)\end{array}$ & 110,537 & 50,957 & $32 \%$ \\
\hline
\end{tabular}

Source: Gustman, Steinmeier and Tabatabai (forthcoming), Table 9.16. 
Table 6 shows the share of household pension wealth due to men and women. It reports results for the three HRS cohorts at the time those 51 to 56 years old entered the survey. The last column of the table highlights the importance of the growth in pension wealth due to women in the household. The share of total pension wealth due to women in households with at least on person 51 to 56 increased from 21 percent in 1992 to 32 percent in 2004.

D. Total Wealth, Pension Wealth and Social Security Wealth Held by Members of Different Cohorts The next step in our analysis is to examine the trends in the components of total household wealth among HRS cohorts. Table 7 compares values for total wealth, pension wealth and Social Security wealth for those 51 to 56 years old in the three HRS cohorts: members of the original HRS cohort who were 51 to 56 year old in 1992; members of the war baby cohort 51 to 56 in 1998; and members of the early boomer cohort 51 to 56 in 2004. All values are reported in 1992 dollars, so the values can be directly compared. To reduce measurement error, the top and bottom one percent of wealth holding households are eliminated.

Total wealth for the early boomer cohort is roughly 12 percent higher than the wealth of the HRS cohort $(458,846 / 409,765)$. Pension wealth accounts for a slightly smaller share of total retirement wealth in 2004 (23.7 percent) than in 1992 (24.0 percent). ${ }^{4}$

The largest share of total wealth is accounted for by Social Security. ${ }^{5}$ In 1992 Social Security represented 30.2 percent of the total wealth of households, and 43.5 percent of the wealth of the

\footnotetext{
${ }^{4}$ Pension value is based on self-reported data. It includes pension values from any current/last and previous jobs. The pension value from a current job includes the calculated prorated projected pension value from the most important DB plan and current account balances from all DC plans. Households with top and bottom one percent of total wealth are excluded. For values of defined benefit plans based on matched employer data, see Gustman, Steinmeier and Tabatabai (forthcoming).

${ }^{5}$ If respondents are retired, benefits are evaluated as if both spouses claim their benefits at the time of the survey. Benefits for respondents and their spouses who had already retired and started receiving benefits are based on their actual receipt. For households where one member was already receiving benefits at the time of the survey, and the other had not yet retired, their benefits are the sum of their
} 
median ten percent of wealth holding households. By 2004 the share of average wealth represented by Social Security was 27.9 percent of total wealth, and to 42.7 percent of the total wealth for the median ten percent of wealth holding households.

As we will see, the importance of Social Security as a source of wealth for the retirement age population is an important reason why the retirement age population will suffer only modest losses in their total retirement savings from the decline in the stock market.

Now consider separately the situation for one earner and two earner households, and the benefits attributable to men and women. The last three panels in Table 7 compare total wealth, Social Security wealth and pension wealth across households consisting of single males, single females and couples. Couple households have much higher wealth of all types than do single households, and single households with males have higher wealth than single households with females. The gap in wealth and the components of wealth between households with single males and single females is falling over the period 1992 to 2004.

E. Conclusion

Having reviewed the trend pensions, its changing role in wealth for the retirement age population, and the role of Social Security, we now turn to an examination of the effects of the decline in the stock market on the retirement age population. Those wishing more information on these trends and other pension related outcomes in the Health and Retirement Study are invited to examine our book, Pensions in the Health and Retirement Study.

actual claim and projected values. But for this group only, we were unable to include survivor benefits and top-up benefits based on spouse's earnings, causing a slight downward bias in estimated Social Security wealth. The basic data underlying these calculations was provided by Kapinos et al. (2008). 
Table 7: Total Wealth, Pension Wealth, and Social Security Wealth by Household Members: Ages 5156 in 1992, 1998, and 2004- Weighted (\$1992)

\begin{tabular}{|c|c|c|c|}
\hline Household Members & HRS & War Babies & Early Boomers \\
\hline \hline All Households & & & \\
Total Wealth & 409,765 & 427,728 & 458,846 \\
Pension Wealth & 98,186 & 109,270 & 108,896 \\
SS Wealth & 123,953 & 117,156 & 127,843 \\
Number of HH & 4442 & 2602 & 2708 \\
\hline One Member HH (Males) & & & \\
Total Wealth & 277,352 & 252,924 & 271,063 \\
Pension Wealth & 78,709 & 59,021 & 67,862 \\
SS Wealth & 71,528 & 65,185 & 307 \\
Number of HH & 402 & 190 & 223,259 \\
\hline One Member HH (Females) & & & 49,293 \\
Total Wealth & 178,752 & 202,410 & 61,574 \\
Pension Wealth & 33,071 & 44,434 & 614 \\
SS Wealth & 54,307 & 53,192 & 1,787 \\
\hline Number of HH & 793 & 383 & 562,963 \\
\hline Two Member HH & 3,247 & 136,866 \\
Total Wealth & 485,183 & 519,016 & 158,508 \\
Pension Wealth & 116,695 & 135,530 & \\
SS Wealth & 148,616 & 143,485 & \\
Number of HH & & 2,029 & \\
\hline \hline
\end{tabular}

Source: Gustman, Steinmeier and Tabatabai (forthcoming, Tables 12.1B, C and D and Table 12.2). Note: Married respondents whose spouses were not interviewed are included in the two member household category. Households with the top and bottom one percent of total wealth are excluded. 



\title{
What the Stock Market Decline Means for the Financial Security and Retirement Choices of the Near-Retirement Population
}

\author{
Alan L. Gustman, Thomas L. Steinmeier, and Nahid Tabatabai
}

\begin{abstract}
The second part of this paper investigates the effect of the current recession on the retirement age population. Data from the Health and Retirement Study suggest that those approaching retirement age (early boomers ages 53 to 58 in 2006) have only 15.2 percent of their wealth in stocks, held directly or in defined contribution plans or IRAs. Their vulnerability to a stock market decline is limited by the high value of their Social Security wealth, which represents over a quarter of the total household wealth of the early boomers. In addition, their defined contribution plans remain immature, so their defined benefit plans represent sixty five percent of their pension wealth. Simulations with a structural retirement model suggest the stock market decline will lead the early boomers to postpone their retirement by only 1.5 months on average. Health and Retirement Study data also show that those approaching retirement are not likely to be greatly or immediately affected by the decline in housing prices. We end with a discussion of important difficulties facing those who would use labor market policies to increase the employment of older workers.
\end{abstract}


The Dow Jones Industrial Average peaked at 14,164 in October 2007. As of tax day, April 15, 2009, it was just below 8,000, a decline of 43 percent. By September 14, 2009, it had recovered to above 9,500, a decline of one third. Those unfortunates who have already retired, can do little about a loss of stock market wealth, or of housing wealth. At the other end of the age spectrum, younger workers had some decades ahead to adjust their work, savings, and investment choices before they face retirement. In this paper, we focus on those workers in their mid 50s, who are on the cusp of retirement.

These workers are of particular interest for several reasons. Since members of this cohort are approaching retirement age, they do not have much time to adjust their saving behavior to offset any capital losses. Some hold that this group may also be more vulnerable to drops in the stock market than earlier generations, because of the shift in recent decades from defined benefit pension plans (pension plans that provide yearly income for life, funded by the employer, where a formula determines the benefit based on earnings, age and service) to defined contribution pension plans (pension accounts such as $401 \mathrm{k}$ or $403 \mathrm{~b}$ plans, established in the name of the worker, funded by contributions from the worker and/or the firm, and invested in assets including stocks). These accounts are frequently invested at least partially in the stock market, and have lost value as a result of the stock market decline. There also has been speculation that the decline in the stock market will cause many workers who were on the cusp of retirement to delay any such plans.

We begin by looking at the wealth of those in the near-retirement group; in particular, from a survey of those in the 53-58 age bracket as of 2006. When we include the wealth from expected Social Security benefits, along with pensions, housing wealth, and other assets, and realize that defined benefit plans continue to dominate their pension wealth, just 15.2 percent of 
the total wealth of this group was invested in the stock market, through defined contribution plans, Individual Retirement Accounts and direct stock holdings. For most of those approaching retirement age, while losing several percentage points of this total is certainly a significant average loss - and is of greater significance for those who are more exposed to the stock market and will experience even larger losses-- these losses will not be life-changing. Many of these households also have two earners in their household, which provides another cushion against the blow of stock market losses.

We then examine the likely effects of the stock market plunge on retirement behavior. An examination of the effect of the dot com bubble on retirement suggests that stock price changes of this order of magnitude have only a modest effect on the retirement decisions of older persons, changing retirement age by only a few months on average. Even if the stock market decline, taken alone, modestly decreases the number of retirements, the recession that started in 2007 may substantially increases retirement due to poor job prospects. Thus, the net effect of a deep recession and a falling stock market may be an overall increase in retirements.

The decline in housing prices and changes in mortgage debt then enter the picture. Although the decline in housing prices is substantial, not many in the "early boomer" population of those in their mid 50s will find their housing wealth under water, with negative equity as their loans exceed the gross value of their house, and many in this population will have already paid off most or all of their mortgages. Moreover, most will not wish to cash out their home equity for many years to come, affording time for the housing market to recover.

The combination of these various effects of the stock market decline, recessionary pressures in the labor market, and decline in housing wealth may well hit a segment of the nearretirement population hard. An older person who has experienced a layoff has a good chance of 
being forced into retirement, meaning that fewer resources will have to be spread over a longer retirement period, and even if the older individual finds another job, it will most likely be at a much lower wage than was earned on a long term job (Chan and Huff Stevens, 2004). New survey data collected by Rohwedder (2009) for Rand suggests that some will be subject to the combined effects of layoffs and wealth losses. As a result they may be unable to meet mortgage obligations, and at the same time face the prospect of selling their homes near the bottom of a down market.

We conclude with some policy implications and conclusions. A major challenge will be that the pattern of financial losses, job losses, and real estate stress will differ greatly among members of the near-retirement age population. Targeting policy just at those most affected will be difficult, Moreover, most of those who suffer large financial losses will come from the upper part of the wealth distribution, which undermines the rationale for policy initiatives that would support all or most of those who have suffered in the downturn.

\section{Potential Losses from the Decline in the Stock Market}

For evidence on those near retirement, we turn to the "Early Boomer" cohort of the Health and Retirement Study (HRS). This cohort includes 2,492 households with at least one member age 51 to 56 in 2004. ${ }^{6}$ Observations are from 2006, two years after most of those in the early boomer cohort entered the Health and Retirement Study. Data from the 2008 wave of the Health and Retirement Study were not available at the time this article was written, but most of the data collected in that wave were collected before the stock market began its sharp decline.

\footnotetext{
${ }^{6}$ Some members of the early boomer cohort were first interviewed before their cohort entered the Health and Retirement Study in 2004. They are younger spouses from households where the older spouse qualified the household for inclusion in the Health and Retirement Study in either 1992 or 1998.
} 


\section{The Components of Total Wealth}

To set the stage for the analysis of the vulnerability of the retirement age population to the decline in the stock market, household wealth for this cohort is disaggregated into its basic components. In the initial description of the importance of different retirement assets, particular attention is paid to the roles of Social Security and pensions in retirement wealth.

By 2006, as seen in row 1 of Table 1, early boomer households had accumulated an average of $\$ 766,945$ in total wealth, with the median 10 percent of wealth-holding households owning \$536,997 in total assets. Social Security and pensions combined to account, on average, for 49.1 percent of total wealth. For the median ten percent of wealth holding households, Social Security and pensions together account for sixty percent of total wealth.

As seen by comparing the value reported in row 3, column 1 of Table 1 to the other values in column 1, the present value of Social Security is the single biggest asset. Earnings histories are obtained from the Social Security Administration with the permission of the respondent. Monthly benefits are then calculated from those histories assuming the respondent retires immediately so that Social Security wealth is prorated based on work to date. Calculating Social Security wealth requires placing a present value on the expected stream of future payments. Social Security wealth includes benefits based on own earnings, and if married based on spouse's own earnings, as well as spouse and survivor benefits if relevant. Social Security wealth then is calculated using the intermediate assumptions from the Social Security Administration, including a 5.8 percent nominal discount rate, 2.8 percent inflation and 1.1 
percent real wage growth. ${ }^{7}$ Based on this calculation, Social Security wealth represents over a quarter of total wealth (26.1 percent), and 40 percent of the total wealth of the median ten percent of wealth- holding households.

Pensions are the second largest asset, accounting for 23.0 percent of average wealth. Respondents holding defined benefit plans report the annual benefits they would receive if they retired at their expected retirement age. Again, the present discounted value of wealth from the future payments of defined benefit plans expected by respondents is calculated using the intermediate assumptions from the Social Security Administration, including a 5.8 percent nominal discount rate, 2.8 percent inflation and 1.1 percent real wage growth. ${ }^{8}$ In addition, the benefits of defined benefit plans are prorated on the basis of work to date. (For those expecting benefits from previous jobs, it is calculated as the present value of those benefits as of 2006. For those already collecting from a defined benefit plan, it is the present value of remaining benefits as of 2006.) Wealth in defined contribution plans is measured by respondent reports of account balances. Table 1, line 5, shows that 15 percent of total wealth is held in defined benefit plans. From line 6, only 8 percent of total wealth is held in defined contribution accounts. Thus, despite the rapid growth in coverage by defined contribution plans in recent decades, such plans held by

\footnotetext{
${ }^{7}$ The 5.8 percent discount rate is the steady state rate for the period preceding the financial decline (U.S. Social Security Administration, 2004). Note that given the risks to full payment of both Social Security and defined benefit plans, one could argue for using a higher discount rate. On the other hand, the real interest rate will also change, declining in the period immediately following the downturn, and increasing after that. The present value calculations were provided by Kapinos et al. (2008).

${ }^{8}$ According to the latest report of the Board of Trustees (U.S. Social Security Administration, 2009), as a result of the financial decline, interest rates are expected to stay below 5 percent through 2011, then fluctuate between 5.6 and 6 percent until 2017, when they return to a steady state rate of 5.7 percent. The relatively modest decline in interest rates in the short run from the 5.8 percent rate assumed in our calculations would increase the value of defined benefit plans and would have only a small effect on the present value of Social Security benefits to be received by this cohort.
} 
the early boomer population account for only a little over a third (35 percent) of their total pension wealth. (Wealth in Individual Retirement Accounts often originates in defined contribution pensions, so that some older defined contribution plans appear as part of IRA balances reported below.) $)^{9}$

The value of the home, defined as the value of the house net of any mortgage or other home loan, represents 22 percent of total wealth. With little direct need to be aware of housing prices, one might doubt whether prices reported by the near-retirement age population fully reflect current market prices, but Bucks and Pence (2006) report that most people are well informed about their housing values. (We will have a more to say about the relation of home values to mortgage values below.) Real estate, business assets and vehicles account for another 12.2 percent of assets. Financial assets account for 9.8 percent of total wealth, with IRA assets accounting for the remaining 6.8 percent.

Table 2 presents the breakdown of wealth for couple households and households consisting of single males and single females. One way to gain perspective on these figures is to compare the figures for couples with the sum of a single male and single female. For example, total wealth is $\$ 131,386$ higher on average in couple households than in the sum of single male and single female households. Social Security wealth held by couple households is more than 12 percent greater than the sum of Social Security wealth in single male and single female households. Couple households also have much higher pension wealth (\$216,220 vs. \$158,932). The differences in benefits in favor of couple households are the result of higher earnings for

\footnotetext{
${ }^{9}$ Upon entering the Health and Retirement Study, 6.6 percent of those in the "early boomer" cohort reported they had rolled over a defined contribution pension from a job held previously into an IRA, with the average value of the roll over equal to \$83,698. Similarly, 2.4 percent of those in the early boomer cohort reported having rolled over a defined benefit plan from a previous job into an IRA with an average value of \$44,345. For further details, see Gustman, Steinmeier and Tabatabai (forthcoming, chapter 11).
} 
men in couple versus single households. In 2004 earnings in all households of single men averaged $\$ 27,560$, while earnings by men in couple households averaged $\$ 48,798$. For women from single households, earnings averaged \$25,157, while women from couple households had average earnings of $\$ 25,995$.

Table 3 indicates how assets are distributed for households falling within different wealth deciles. As seen in row 3, as total wealth increases, Social Security wealth declines as a share of total wealth; conversely, row 4 indicates that pensions increase in importance as total wealth rises. Together, the share of total wealth due to the sum of Social Security and pensions declines, but the decline is steady and modest through the ninetieth percentile. Comparing rows 5 and 6 , the share of total wealth due to both defined benefit and defined contribution pensions increases by wealth decile. At the ninth decile, defined benefit pensions are more than twice as important as defined contribution pensions. The share of wealth held in IRAs increases with wealth decile. In contrast, although the share of total wealth in housing increases through the bottom half of the wealth distribution, it remains between 22 and 23 percent for those in the top part of the distribution. The share of total wealth held in stocks rises from 1.5 percent in the lowest decile, to 22.6 percent in the highest. (As noted under Tables 1-3, these totals exclude both the top and bottom 1 percent of households as a way of addressing measurement error problems.)

\section{Exposure to the Stock Market Decline}

We use the share of wealth in stocks as an indicator of a household's vulnerability to a stock market decline. Consider first the total share of the wealth in defined contribution plans held in stocks. Of the $\$ 61,621$ average balance in defined contribution plans indicated in line 6 of Table 1, \$44,506 comes from plans held on the current job. In 2006, on average, almost 62 percent $(\$ 27,470 / \$ 44,506)$ of total assets held in pensions on current jobs was held in stocks. We 
use the share of assets from defined contribution plans on current jobs held in stocks by each individual to approximate the share of total pension wealth from current and past jobs held in the form of stocks. ${ }^{10}$ This yields a value of $\$ 38,801$ for our estimate of the total value of defined contribution balances held in stocks.

Individual Retirement Accounts are a second asset with direct holdings in stocks. On average, 6.8 percent of total wealth is in the form of IRA assets, with 74 percent $(38,452 / 52,270)$ of IRA balances held in stocks. In addition, direct stock holdings represent 5.1 percent of total wealth.

Taking the sum of defined contribution pension accounts held in stocks, IRA holdings in stocks, and direct stock holdings, that yields 15.2 percent of total wealth $(\$ 116,535 / \$ 766,945)$ held in the form of stocks. Thus, a substantial and permanent decline in the stock market from its 2006 level means an average fall of several percentage points in average wealth. This loss is a significant one: percentage points of personal wealth should never be taken lightly. But it is not a life-changing loss for the average household. We will return to the question of the distribution of losses below, but before turning to that issue, consider the reasons for the relatively small exposure to the stock market decline on average.

\footnotetext{
${ }^{10}$ Note that the share of defined contribution plans held in stocks is reported only for those who report their defined contribution plan separately from any defined benefit plan they might hold. When a respondent is asked plan type and reports holding "Both" a defined benefit and a defined contribution plan as the initial response, the Health and Retirement Study does not ask about the share of pensions in the stock market in the defined contribution plan. For these individuals, the share of the defined contribution part of the account held in stocks is imputed based on the share of defined contribution plans held as stocks by individuals who have reported having two plans from their employer, one a defined benefit and the other a defined contribution plan, reporting those plans separately rather than as having "both" plan types. Similarly, the Health and Retirement Study does not ask about the share of pensions from previous jobs that are held in stocks. The share of assets in last or previous plans held in stocks is imputed from stock holdings in pensions on current jobs.
} 
One answer is that 34.6 percent of households report they have no assets in stocks. When we average the ratios of stock value to total wealth, the mean is 9.43 percent, which is significantly below the ratio of total stock value to total wealth of 15.2 found in Table 1 . About 67 percent of the households have a ratio of stock value to total wealth that falls below the mean of the ratios. The share of those who own no stocks declines as we move up the wealth distribution, but there are some stock holders in each wealth decile. Thus on the one hand, 8.9 percent of the population falls both in the lowest wealth decile and has nothing invested in stocks. On the other hand, 5.0 percent of the population falls in the upper wealth decile and has a ratio of total wealth in stocks to total wealth that falls in the top two deciles of that distribution.

Why do so few households choose to own stocks, and why is the share of total wealth in stocks so low? One reason is the high value of Social Security. The magnitude of Social Security wealth tends to make the share of assets in stocks smaller than might be expected for most of the population. $^{11}$

Another reason for the limited direct exposure of the retirement age population to the stock market decline is the incomplete status of the transition from defined benefit to defined contribution plans for the population now approaching retirement. Remember, despite the strong trend to defined contribution pension plans over time, just over one-third of the pension wealth of this near-retirement population is held in a defined contribution plan. Much of this difference seems to stem from the fact that for the "Early Boomer" cohort, pension tenure averages 16.8

\footnotetext{
${ }^{11}$ Social Security also provides good news from an insurance perspective. Because Social Security benefits are based on the highest 35 years of earnings, and benefits are determined by a progressive formula, for most households Social Security benefits are relatively insensitive to any earnings lost due to layoffs late in the career. Of course, layoffs may induce claiming of Social Security benefits earlier in life. But while this reduces annual benefits, the total actuarial value of Social Security wealth over the lifetime is not greatly affected by the choice of when to start claiming benefits.
} 
years for those with a defined benefit plan, while averaging 9.7 years for those with a defined contribution plan—a ratio of 1.73 (Gustman, Steinmeier and Tabatabai, forthcoming). Similarly, the ratio of pension values between defined benefit and defined contribution plans held by this cohort of households in 2004 is 1.86 to one. This pattern suggests that almost the entire difference in plan values between defined benefit and defined contribution plans may be due to the current immaturity of defined contribution plans. Indeed, Samwick and Skinner (2004) predict that defined benefit and defined contribution plans will have similar values in the long run.

To be sure, defined benefit plans are vulnerable to stock price declines, as firms and local governments may find that they have not put aside enough money to finance promised benefits. But in many circumstances, wealth in the form of a defined benefit plan held by those approaching retirement age is less subject to change than are the promised payments of defined benefit plans for younger workers. Older workers have often been grandfathered and exempted from major plan changes, or changes have built-in lags, further postponing any action that might otherwise affect older workers. Many of those who are forced to retire early receive additional service and wage credits, mitigating any penalty for failing to stay until they qualify for early retirement benefits. Unless the firm is bankrupt, benefits cannot be reduced below the levels promised on the basis of work to date. In addition, benefits from private sector defined benefit plans are insured by the Pension Benefit Guarantee Corporation, although there is a cap on the insured benefit of $\$ 54,000$ for a 65 year old in 2009 .

Thus the combination of high Social Security benefits, continued importance of defined benefit plans, the immaturity of defined contribution plans, and the failure of almost 35 percent 
of all households to participate in the stock market, all account for the low exposure of the retirement age population to the decline in the stock market.

Now let us consider the distribution of wealth losses from the stock market decline in somewhat more detail. From the baseline data on the distribution of wealth held in stocks in the bottom row of Table 3, we have seen how the potential vulnerability to the stock market decline varies according to wealth decile. Exposure to stocks ranges from 1.5 percent to 7.4 percent for those in the bottom five deciles of the wealth distribution. ${ }^{12}$

Again, Social Security plays a central role in the story. Those in the lower wealth deciles are heavily dependent on Social Security. Looking across row 3 of Table 3, Social Security wealth accounts for 65 percent or more of the total wealth of those in the bottom three deciles of the wealth distribution. In contrast, those in the top wealth decile have only 11.1 percent of their total wealth from Social Security.

The extent of exposure to stocks seems relatively modest even for those in the highest wealth decile. As seen in the bottom row, last column of Table 3, those in the top 10 percent of the wealth distribution (with the top 1 percent having been removed) hold less than a quarter (22.6 percent) of their total wealth in stocks. The good news here is that those who have been hurt the most by the stock market decline are among the wealthiest in the country and are able to absorb the losses without entering the ranks of the poor. However, any public policy plans that were predicated on higher taxes for the wealthy look less attractive and politically viable when the amount of wealth has just declined substantially.

${ }^{12}$ Overall, 34.6 percent of the population does not own stocks, but the share of total wealth in stocks is positive, even for those in the lowest wealth decile (as shown in Table 3). The reason behind what may seem like an inconsistency in the data is that the share of those who own no stocks declines as we move up the wealth distribution, but there are some stockholders and nonstockholders in each wealth decile. 


\section{Retirement and a Stock Market Bubble}

It will take some years before it is possible to measure the effects on retirement of the stock market decline of 2008-2009, and to separate the effects of the stock market decline on retirements from the effects of layoffs and high unemployment on retirement. However, the U.S. economy recently experienced another episode of a rapid increase in stock prices, followed by a sharp decline - the episode often known as the dot-com bubble. Using a structural model of retirement and saving estimated with panel data from the original sample in the Health and Retirement Study, and using parameters fit from analysis of the 1996-1999 boom in stock prices, it is possible to use simulations of the model to obtain an idea of the effects of changes in stock market prices alone on retirement behavior.

The model we use is a life cycle model with stochastic returns to wealth. Utility in each year is a function of leisure and consumption:

$$
U=\sum_{t=0}^{N} e^{-\rho t} S_{t}\left[\frac{1}{\alpha} C_{t}^{\alpha}+e^{\beta X_{t}+\varepsilon} L_{t}\right]
$$

subject to the usual intertemporal budget constraint, where $\mathrm{s}$ is the survival rate, $\mathrm{X}$ is a vector including age and health, and $\mathrm{L}$ takes on a value of 1 if the individual is retired and 0 otherwise. In such a model, an above-average increase in stock market wealth produces a positive income effect which should increase the consumption of all normal goods, including leisure. Since the work-leisure choice in this model is binary, the increased lifetime leisure takes the form of earlier retirement.

The model allows individual heterogeneity in both time preference $(\rho)$ and the preference for leisure vs. work $(\varepsilon)$. The heterogeneity in time preference allows the model to capture the wide variation in wealth even for individuals with similar lifetime earnings opportunities. The 
heterogeneity in leisure preferences is equivalent to a variation in retirement preferences, given the binary work-retirement decision, and allows the model to capture the variation in retirement outcomes of similarly situated individuals. After the individual retires, the model also allows for unexpected changes in retirement preferences to reflect that some individuals find retirement more enjoyable than expected, and some find it less enjoyable.

The lifetime resources include earnings, Social Security, and pensions. The model is estimated from data in the Health and Retirement Study through 2000, which includes the stock market boom of the late 1990s. The sample for both the estimation and simulations is the original Health and Retirement Study participants, which included families with at least one spouse born between 1931 and 1941. This data set is unique in that it contains (for most respondents) Social Security earnings records and pension descriptions from employers, both of which are used in the estimation. Financial wealth, including assets in defined contribution accounts, is presumed to be half in stocks and stock funds, roughly consistent with estimates from the Health and Retirement Study for the middle part of the wealth distribution. The distribution of returns is presumed to be known and is taken from Ibbotson (2002) data, but of course individuals do not know future returns when they are making their retirement and savings decisions in a given year.

For both estimation and simulation, the model is solved using a stochastic dynamic approach which solves for labor supply and consumption over the entire life cycle. The estimated model parameters allow the model to reproduce the actual patterns of retirement fairly well, including the pronounced spike of retirement at age 62 and the percentage of individuals who return to full-time work after a period of retirement. Further details of the model and its estimation are found in Gustman and Steinmeier (2002). 
In the five-year period starting in 1995, the stock market rose by almost 21 percent per year compounded. Since inflation was relatively low at the time, almost all of this increase represents an increase in real value. A typical stock portfolio would have been worth about twoand-a-half times as much at the end of the five years as at the beginning. Since annual stock returns exhibit little serial correlation, it seems safe to assume that these returns were largely unanticipated. And then the bubble burst. During the period from the beginning of 2000 to the end of September 2002, the market fell by 13 percent per year. From the market peak until August 2002, the cumulative decline was 34 percent, so that a little more than a third of stock market wealth evaporated in two years. This is similar in magnitude to the decline in the stock market in the recession of 2008-2009.

We first consider the effects of the stock market boom on retirement. For this analysis, we will consider the boom to be the years 1995 through 1999. To simulate the effects of the stock market boom on retirement, we do two simulations. In one simulation, normal returns are assumed for the years 2000 and beyond. In the other simulation, normal returns are assumed for the years 1995 and beyond. In other words, the difference between these two simulations will represent the effects on retirement of five years of high returns.

Figure 1 reports on the differences between these two simulations. In this figure, the height of the bars represents the difference in the percentage of individuals retired in the specified year (and thus not the number of individuals newly retiring in that year). For instance, the bar in 1999 reflects that in the base simulation 63.2 percent of the sample was retired, while in the simulation with higher stock market returns 66.5 percent was retired. The shaded parts of the bars indicate the difference in retirement by individuals who have not been previously retired, and the white parts of the bars indicate the difference in retirement caused by individuals 
staying retired rather than returning to work. The total heights of the bars thus indicate the total difference in retirement. The difference in new retirements is somewhat but not overwhelmingly more than the difference in retirement caused by individuals not returning to work.

The volume of retirements in Figure 1 is higher in each year during the period of the high stock market returns. At its peak in 1999, the percent retired in the sample is about 3.3 percentage points higher than it would be without the extra stock returns. The effect continues long after 1999, since the extra returns apply not just to those who retire during this period, but to individuals who would be retiring in the succeeding years. As time goes by, however, the effect of those returns gradually diminishes, both because individuals will have longer to adjust consumption to the higher levels of assets and because more and more of the sample would have retired anyway.

To find the effect on the average retirement age, we note that the bar for 1996 means that with the stock market boom, 1.2 percent of the sample would have been retired for one additional year. For 1997, 1.7 percent would have been retired one additional year, 2.9 percent for 1998, and so on. Adding the effects for the various years, including years beyond 2003 not shown in the graph, we find that a total of $25 \%$ of the sample would have been retired for one additional year. This yields the conclusion is that the average length of retirement would be increased by 0.25 years, or about three months, and the average age of retirement would be reduced by a corresponding amount. This figure implies that at least three-quarters of the sample would not have changed their retirement date as a result of the stock market boom, which is consistent with the previously documented fact that a large minority of the sample had no or only limited financial assets. Moreover, the magnitude of this effect appears reasonable. According to Venti and Wise (1999, Table 4), the average respondent had about \$79,000 in financial and retirement 
assets in the first wave of the survey. The 1995-1999 surge in the stock market would cause a portfolio of 50 percent stocks to have risen by about 60 percent more than the usual increase, so the unexpected gain would have been around $\$ 47,000$, or somewhat more than a year's worth of average earnings. The simulated decrease of 0.25 years in the average retirement age indicates that respondents do take part of this unexpected gain in the form of increased retirement, but that the major part of it goes toward increased consumption. Others who investigated the effects of the dot com bubble on retirement reached similar conclusions, like Coronado and Perozek (2003) and Hurd, Reti and Rohwedder (2009).

Figure 2 considers an analogous exercise to analyze the effects of the sharply lower stock prices in the early years of the new century. The figure again compares two simulations, one using actual returns until 2002 and normal returns thereafter and the other using actual returns until 1999 and normal returns thereafter. The difference between these two scenarios reveals that between 2000 and 2002, the negative effects on retirement of the stock market declines develop rapidly, reaching a 3.2 percentage point decrease in 2003. The average delay, according to these figures, is 0.125 years, which translates into 1.5 months. The peak effect is approximately the same size and in the opposite direction from the effect of the previous stock market increase. The effect decreases more rapidly from this peak, however, undoubtedly because retirement in this sample is much further along in 2003 than in 1999. As a result, the total effect is only about half as much as for the previous stock market increase.

Taking these scenarios together, our story is that the extraordinary returns in the stock market in the late 1990s, which more than doubled stock prices and unexpectedly increased the value of a mixed portfolio by nearly 60 percent, increased retirement for those near-retirement by over 3 percentage points by the turn of the century and would have decreased the average retirement 
age by about a quarter of a year-if it had not been interrupted. The subsequent decline in the market, which very nearly wiped out the gains that had been made during the preceding surge, effectively neutralized the effect of the preceding stock market gains on retirement, and would have delayed retirements by .125 years, or 1.5 months. The effects of the stock bubble were to increase retirement as long as the bubble continued, but the continuing effects of the bubble after its end are probably minimal.

Based on these findings, we expect the changes in stock market prices from the bear stock market of 2008-2009 to have a slightly greater effect on retirement than the dot com bubble, given the similar change in stock market prices and greater accumulation of assets held in stocks in defined contribution pension plans and Individual Retirement Accounts.

Nevertheless, our findings also suggest that if one combined both the run-up of the stock market in the years before 2007 and the decline of 2008-2009, the net effects of the stock market bust on retirement will be relatively limited.

The distribution of these effects is seen in Table 4. The distribution of the delay in retirement responses reported in Table 4 breaks down the results of Table 3 according to the percentage of simulations where individuals delay retirement. Only 9.6 percent of the sample will delay their retirement by a year or more as a result of the stock market decline, with 7.3 percent of the retirement age population delaying their retirement by one year, and 1.8 percent of the population delaying retirement by two years. From the lofty standpoint of aggregate labor market statistics, these effects do not appear large. But retirement is a major lifetime decision, one that workers often consider and lead up to for some years. Suddenly feeling a need to reconsider a retirement decision and then postponing retirement for a year or more would certainly feel like a substantial misfortune to many retirees. 
Once again, the above figures relate to the effects of wealth changes and do not consider the layoffs that are created by the recession accompanying the decline in stock market prices. The retirements resulting from layoffs are in the opposite direction from the tendency of reduced wealth to reduce retirement. ${ }^{13}$ It is not just that higher unemployment rates depress the probability of finding a job. Even in a nonrecessionary period, most older workers who lose a job are unable to find employment paying anything near the wage they received from a long term employer. Using data from the Health and Retirement Survey, Huff-Stevens and Chan (2001) find, for example, "Four years after job losses at age 55, the employment rate of displaced workers remains 20 percentage points below the employment rate of similar nondisplaced workers.”

One other word of caution is in order. The preceding retirement analysis pertains to the effect of the stock market decline on retirements, holding other changes constant. However, overall changes in labor force participation and retirements of those nearing retirement age also reflect the influence of a host of other factors. There has been a clear increasing trend in the labor force participation of older women. In addition, Social Security rules have been changed to increase the reward to work after normal retirement age. There have been changes in provisions of defined benefit pensions that reduce the penalty to delayed retirement. There is the trend to defined contribution plans, and laws and court rulings against age discrimination. These and other factors have worked toward increasing the labor force participation of men over 65 (Gustman and Steinmeier, 2009). The trend in labor force participation of men in their fifties and early sixties is less clear, clouded by increasing participation in disability programs. In light of

\footnotetext{
${ }^{13}$ Coile and Levine (2009), using a reduced form relation between retirements and unemployment in CPS data over time, suggest that the increase in unemployment will raise retirements by about twelve percent, but that the entire effect will fall on those 62 to 69 years of age, with no effect on those in their fifties or early sixties.
} 
the influence of all of these factors, one should be very careful in drawing conclusions about the likely effects of the recession on labor force participation and retirement without separating out trend from cycle.

\section{Potential Vulnerability to House Price Declines}

In the last few years, those at the cusp of retirement have not only seen their assets decline because of the fall in the stock market, but also because of the decline in housing prices. To provide an indication of the vulnerability of the "Early Boomer" population to the housing price decline, Figure 3 shows the cumulative distribution of the ratio of mortgage value to house price for this group as of 2006. ${ }^{14}$ As seen on the y-axis, 46.4 percent of Early Boomer households had no mortgage. ${ }^{15}$ One-fifth of early boomer households (22.8 percent) had zero house value and were presumably renters. For members of the "Early Boomer" cohort with a positive home value, the mortgage amounts to 38.9 percent of the home value. (The average of the ratios of mortgage to home value is 24.9 percent.) The dotted vertical line in Figure 3 at 100 represents a ratio of mortgage to house value of one to one. Only 1.7 percent of the early boomer households lie to the right of 100 , and thus had a house value lower than their mortgage obligation in 2006. If housing prices declined by 20 percent to the vertical line at $80,6.4$ percent

\footnotetext{
${ }^{14}$ Twenty households with a mortgage greater than 200 percent of the reported house value have been excluded from the figure.

${ }^{15}$ The Health and Retirement Study has oversampled minority populations. In addition, some members of the early boomer cohort may have initially been sampled before 2004 as younger members of households with a spouse in an age range that qualified the household for inclusion in an older cohort. Both factors affect an observation's sample weight. Figure 3 and related percentages and means describing home ownership and mortgage holding are not weighted, but using weights does not make a substantial difference here. With weights, the percent of households without any mortgage mentioned in this paragraph is 43.2 percent. With weights, the percent of renters is 19.0 percent.
} 
of the early boomer population would be in a position where their housing value on current markets would fall below what they owed on their mortgage. But for most of those who would be under water, the gap between their house value and mortgage would be relatively small. ${ }^{16}$

There is a more fundamental question that should be addressed -- should housing wealth be included among the sources of wealth that will support consumption in retirement? Venti and Wise (2004) conclude that for the most part, older persons hold their housing to provide an environment in which to live, not to finance general retirement consumption. They find that most households do not draw down their housing wealth, even when they move. Households that do draw down their housing wealth are those that experience a precipitating shock in terms of health or death of a spouse. Thus while households may consider housing as a buffer insuring against catastrophic circumstances, they do not consider the house as a source of support for consumption. This might argue in favor of excluding housing wealth from the list of assets owned by the household. However, home ownership does support housing consumption. Moreover, there are financial implications of the decline in housing prices not only for those who are under water, but also for those who upgraded their homes in expectation of continuing capital gains. Thus we include housing wealth along with other assets to distinguish between those households who must pay rent and those who will not have to devote assets toward rent, in view of the role of housing as a buffer against catastrophic events, freeing other assets to support consumption, and in view of the financial implications for those who considered their homes to be an investment. All of that said, in most cases the retirement consumption of those nearing

\footnotetext{
${ }^{16}$ Of course, a more precise analysis would allow for geographic variation in the decline in housing prices, but one cannot use the restricted pension and Social Security data from the Health and Retirement Study and at the same time have access to geographic detail. For further discussion and findings, see Rohwedder (2009).
} 
retirement will be little affected by the fall in housing prices. Nor do we expect the fall in housing prices to have a major effect on retirements.

To be sure, those within the Early Boomer population in deepest trouble will be those suffering multiple adverse events. From Table 3, row 8, moving up the wealth distribution, both the share of total wealth in housing (net of mortgages) and the share of total wealth in stocks increase. Those in the top wealth decile have 22 percent of their wealth in housing and an additional 23 percent of their wealth in stocks. A twenty percent decline in housing prices would reduce the total wealth of those in the top decile by about 4.5 percent, to be compounded with a 7.5 percent decline in wealth due to a stock market decline of one third. We also examine the correlation between share of wealth in stocks and immediate vulnerability to a stock market decline by correlating the share of total wealth in stocks with the ratio of housing equity to total value of the house. The correlation is zero.

Perhaps even more troubling than the separate effects of the declines in the stock market and housing market, job loss itself may trigger multiple adverse events. For example, those without jobs will be less likely to meet their mortgage payments and will be in the greatest danger of losing their homes. Job losers who wish to move to a new location to take a new job may not be able to sell their homes in a short time without heavily discounting the price.

Those experiencing layoffs aside, as our discussion above indicates, the decline in housing prices is likely to have a less immediate impact on consumption in retirement than will the fall in stock prices. Most people in their 50s are unlikely to sell their homes for many years -until one spouse becomes ill or dies. Thus, again with the notable and important exception of those who experience a job layoff, a decline in housing prices may have a less immediate effect on the population approaching retirement age than the decline in other asset prices. 


\section{Policy Implications and Conclusions}

The average person approaching retirement age is not likely to suffer a life changing financial loss from the stock market downturn of 2008-2009. To some extent, average households on the cusp of retirement are shielded by the fact that stock market holdings do not loom especially large in their overall wealth. In addition, the near-retirement generation is more likely than younger generations to have a defined benefit plan as a primary pension, rather than a defined contribution plan, which also cushions the decline in wealth due to a stock market decline. In part because of the limited effect of the stock market decline on the near-retirement age population, the effect of the decline on retirements is likely to be very limited. Indeed, when account is taken of involuntary job loss and limited opportunities for employment at pay comparable to that received on a long term job, retirements may be accelerated as a result of the stock market decline and recession rather than deferred.

This is not to argue that the effects of the downturn are small. Stock market losses aside, many will have lost jobs and homes. In this circumstance, our instinct is often to redesign or adopt new policies. However, in dealing with the older population, it is no easy task to think of policy changes that will be cost effective in remedying obvious market and policy failures. Indeed, there are many reasons not to leap to policy reform on the basis of our recent experience.

Efforts to bail out the big losers, who are those with high levels of wealth, are a nonstarter. One might also advocate additional policies to encourage adoption of a more prudent asset mix by those approaching retirement age. Pension providers should certainly continue to remind those approaching retirement age about the risks from defined contribution plans with portfolios that are overwhelmingly invested in stocks. But those approaching retirement are now better aware of those risks. Moreover, absent investments in inflation indexed securities, they 
face the danger from overreliance on fixed income securities that will generate declining real incomes over time. One might also advocate increased support for defined benefit plans. Although defined benefit pensions played a useful role in cushioning against the market decline, today we are far from having the kind of industry and union structure that made these plans a stable and reliable source of retirement incomes. It is unlikely that any policy initiative will be able to reverse the tide away from defined benefit plans. Social Security provided an important cushion against the market decline, but that would be an inadequate reason for resolving the debate on how best to deal with Social Security deficits by opting for a financially buttressed version of the current system. Our recent experience should not end the debate about whether to adopt incremental reforms to Social Security or to move some of the system toward personal accounts. Although redesign of Social Security should certainly take account of the risks inherent in personal accounts, the higher returns to stocks, and approaches for cushioning Social Security beneficiaries against market declines even when Social Security is supplemented by personal accounts (Feldstein and Rangolova, 2001) should also be taken into account.

Although we could wish for public policies to help those older persons who have been forced into premature retirement or prolonged work at a relatively low wage, labor market policies are especially difficult to target effectively on an older population. For example, encouraging part-time work by the elderly will encourage continued work by some who would otherwise retire from the labor force, but may also result in an equal and offsetting decline in hours of work by those who, in the absence of a policy change, would have continued to work full time instead of choosing to partially retire (Gustman and Steinmeier, 2008). It is also difficult to efficiently target job training and jobs programs on the retirement age population, distinguishing troubled workers from those who are simply in the process of retiring. In the 
absence of a recession, wages would be falling, many would be leaving long term jobs and the labor market, and many would be working part-time at lower wages. Moreover, job training programs for older workers face short payback periods that limit their returns (Hutchens, 1986, 1987). In the absence of any obvious remedies particularly suitable for those approaching retirement age, we may simply be limited to applying the current menu of labor market programs to older as well as prime age workers. 


\section{References}

Bucks, Brian and Karen Pence. 2006. "Do Homeowners Know Their House Values and Mortgage Terms?” Washington, D.C.: Federal Reserve Board of Governors. http://papers.ssrn.com/sol3/papers.cfm?abstract_id=899152

Chan, Sewin and Ann H. Stevens. 2004 "How Does Job Loss Affect the Timing of Retirement?” Contributions to Economic Analysis and Policy 3(1), article 5. http://www.bepress.com/bejeap/contributions/

Coile, Courtney and Phillip B. Levine. 2009. “The Market Crash and Mass Layoffs: How the Current Economic Crisis May Affect Retirement”. NBER Working Paper 15395.

Coronado, Julia L. and Maria Perozek. 2003. "Wealth Effects and the Consumption of Leisure: Retirement Decisions During the Stock Market Boom of the 1990s”. Federal Reserve Board Working Paper No. 2003-20. http://papers.ssrn.com/sol3/papers.cfm?abstract_id=419721

Feldstein, Martin S. and Elena Ranguelova. 2001. "Accumulated Pension Collars: A Market Approach to Reducing The Risk of Investment-Based Social Security Reform". Tax Policy and the Economy 15.(Cambridge, MA: MIT Press)

Gustman, Alan L. and Thomas L. Steinmeier. 2002. "Retirement and the Stock Market Bubble”. NBER Working Paper No. 9404. . 2008. "Projecting Behavioral Responses to the Next Generation of Retirement Policies. Research in Labor Economics 28: 141-196.

Trends.” Research on Aging 31(2): 261-290. 2009. "How Changes in Social Security Affect Recent Retirement

Gustman, Alan L., Thomas L. Steinmeier and Nahid Tabatabai. Forthcoming. Pensions in the Health and Retirement Study. Cambridge: Harvard University Press.

Hurd, Michael D., Monika Reti and Susann Rohwedder. 2009. "The Effect of Large Capital Gains or Losses on Retirement”. In David A. Wise, editor, Developments in the Economics of Aging. Chicago, University of Chicago Press for NBER: 127-163.

Hutchens, Robert. 1986. “Delayed Payment Contracts and a Firm’s Propensity to Hire Older Workers”. Journal of Labor Economics 4(4): 439-457. . 1987. “A Test of Lazear's Theory of Delayed Payment Contract”.

Journal of Labor Economics 5(4) part II: S153-S170.

Ibbotson Associates. 2002. Valuation Edition 2002 Yearbook. Chicago: Ibbotson Associates.

Kapinos, Kandice with Charlie Brown, Michael Nolte, Helena Stolyarova and David Weir. 2008. "Social Security Wealth Measures”. Ann Arbor: Institute for Social Research, Health and Retirement Study. No URL available.

Rand HRS data file. http://hrsonline.isr.umich.edu/modules/meta/rand/index.html Rohwedder, Susann. 2009. “American Life Survey: Evidence on How the Financial Crisis Has Affected American Households”. Paper presented at Michigan Retirement Research Center Research Workshop, April 3 and 4, 2009. No URL available.

Samwick, Andrew A. and Jonathan S. Skinner. 2004. "How Will 401(k) Plans Affect Retirement Income?” American Economic Review 94: 329 - 343.

Stevens, Ann Huff and Sewin Chan. 2001. "Job Loss and Employment Patterns of Older Workers." Journal of Labor Economics 19(2): 484-521. 
U.S. Social Security Administration. 2004. "The 2004 Annual Report of the Board of Trustees of the Federal Old-Age and Survivors Insurance and Disability Insurance Trust Funds". Washington, D.C.: U.S. Social Security Administration. . 2008. "Annual Statistical Supplement to the Social Security Bulletin. Washington, D.C.: U.S. Social Security Administration. 2009. "The 2009 Annual Report of the Board of Trustees of the Federal Old-Age and Survivors Insurance and Disability Insurance Trust Funds”. Washington, D.C.: U.S. Social Security Administration.

Venti, Steven F. And David A. Wise. 1999. "Lifetime Earnings, Saving Choices, and Wealth at Retirement.” In James P. Smith and Robert J. Willis, Editors, Wealth, Work and Health: Innovations in Measurement in the Social Sciences. Ann Arbor, University of Michigan Press, pp. 87-120. . 2004. "Aging and Housing Equity: Another Look". In David A. Wise, editor, Perspectives on the Economics of Aging. Chicago, University of Chicago Press for NBER: 127-175. 
Table 1: Components of Wealth in 2006 For Households with at Least One Member Born from 1948 to 1953: Current Dollars*

\begin{tabular}{||c|c|c|c|c||}
\hline \multirow{2}{*}{ Source of Wealth } & \multicolumn{2}{|c|}{ Mean } & \multicolumn{2}{c|}{$\begin{array}{c}\text { Median 10 Percent Of } \\
\text { Households }\end{array}$} \\
\cline { 2 - 5 } & $\begin{array}{c}\text { Value } \\
(\$)\end{array}$ & $\begin{array}{c}\text { Percent of } \\
\text { Total } \\
(\%)\end{array}$ & $\begin{array}{c}\text { Value } \\
(\$)\end{array}$ & $\begin{array}{c}\text { Percent of } \\
\text { Total } \\
(\%)\end{array}$ \\
\hline \hline Total & 766,945 & 100 & 536,997 & 100 \\
\hline Social Security Plus Pensions & 376,618 & 49.1 & 321,429 & 59.9 \\
\hline Social Security & 200,158 & 26.1 & 215,569 & 40.1 \\
\hline Pension Value & 176,460 & 23.0 & 105,860 & 19.7 \\
\hline DB Value & 114,838 & 15.0 & 74,071 & 13.8 \\
\hline DC Value & 61,621 & 8.0 & 31,789 & 5.9 \\
\hline Current DC Balances & 44,506 & 5.8 & 24,016 & 4.5 \\
\hline Current DC in Stocks & 27,470 & 3.6 & 16,080 & 3.0 \\
\hline Net House Value & 169,090 & 22.0 & 119,899 & 22.3 \\
\hline Real Estate & 36,201 & 4.7 & 17,508 & 3.3 \\
\hline Business Assets & 39,803 & 5.2 & 8,423 & 1.6 \\
\hline Net Value of Vehicles & 17,810 & 2.3 & 17,478 & 3.3 \\
\hline Financial Assets & 75,153 & 9.8 & 27,083 & 5.0 \\
\hline Direct Stocks Holdings & 39,282 & 5.1 & 9,616 & 1.8 \\
\hline IRA Assets & 52,270 & 6.8 & 25,177 & 4.7 \\
\hline IRA in Stocks Value & 38,452 & 5.0 & 18,213 & 3.4 \\
\hline IRA Plus Stocks Holdings & 116,535 & 15.2 & 49,363 & 9.2 \\
\hline Plus DC in Stocks & & 2,493 & & \\
\hline Observations & & & & \\
\hline \hline
\end{tabular}

Note: The values under "Median 10 Percent of Households" are the means of the indicated assets when averaged over the median 10 percent of wealth-holding households. To reduce measurement error, households with the top and bottom $1 \%$ of total wealth are excluded from the table. Observations are weighted. Data on Social Security wealth is from an updated version of Kapinos et al. (2008). Pension wealth is calculated by the authors from respondent reports of expected benefits, actual benefits and account balances. Defined benefit plan values on current jobs are computed on the basis of work to date to make them comparable to values of defined contribution plans. Share of defined contribution pension wealth in stocks is imputed for each observation, including imputations for all defined contribution plans from last or previous jobs. This creates a slight discrepancy between the total of holdings in stocks reported in the table and the share of holdings in stocks that would be computed by multiplying the total defined contribution value by the ratio of current defined contribution holdings in stocks to current defined contribution balances. Other components of wealth are from the Rand HRS data file, including imputations of missing values. 
Table 2: Components of Wealth in 2006 For Couples And Single Males and Females with at Least One Household Member Born from 1948 to 1953: Current Dollars*

\begin{tabular}{|c|c|c|c|c|c|c|}
\hline \multirow[b]{2}{*}{ Source of Wealth } & \multicolumn{2}{|c|}{ Couples } & \multicolumn{2}{|c|}{ Single Males } & \multicolumn{2}{|c|}{ Single Females } \\
\hline & $\begin{array}{l}\text { Mean } \\
\text { Value } \\
(\$)\end{array}$ & $\begin{array}{l}\text { Percent } \\
\text { of Total } \\
(\%)\end{array}$ & $\begin{array}{l}\text { Mean } \\
\text { Value } \\
(\$)\end{array}$ & $\begin{array}{l}\text { Percent } \\
\text { of Total } \\
(\%)\end{array}$ & $\begin{array}{l}\text { Mean } \\
\text { Value } \\
(\$)\end{array}$ & $\begin{array}{l}\text { Percent } \\
\text { of Total } \\
(\%)\end{array}$ \\
\hline Total & 920,517 & 100.0 & 430,046 & 100.0 & 359,085 & 100.0 \\
\hline $\begin{array}{l}\text { Social Security Plus } \\
\text { Pensions }\end{array}$ & 455,094 & 49.4 & 199,505 & 46.4 & 171,856 & 47.9 \\
\hline Social Security & 238,874 & 25.9 & 114,753 & 26.7 & 97,676 & 27.2 \\
\hline Pension Value & 216,220 & 23.5 & 84,752 & 19.7 & 74,180 & 20.7 \\
\hline Males & 159,793 & 17.4 & - & - & - & - \\
\hline Females & 75,852 & 8.2 & - & - & - & - \\
\hline DB Value & 138,218 & 15.0 & 65,922 & 15.3 & 51,070 & 14.2 \\
\hline DC Value & 78,001 & 8.5 & 18,830 & 4.4 & 23,111 & 6.4 \\
\hline $\begin{array}{l}\text { Current DC } \\
\text { Balances }\end{array}$ & 57,002 & 6.2 & 10,003 & 2.3 & 16,470 & 4.6 \\
\hline $\begin{array}{l}\text { Current DC in } \\
\text { Stocks }\end{array}$ & 35,466 & 3.9 & 6,576 & 1.5 & 8,668 & 2.4 \\
\hline Net House Value & 195,897 & 21.3 & 100,942 & 23.5 & 104,571 & 29.1 \\
\hline Real Estate & 45,307 & 4.9 & 22,499 & 5.2 & 7,456 & 2.1 \\
\hline Business Assets & 49,577 & 5.4 & 18,474 & 4.3 & 13,770 & 3.8 \\
\hline Net Value of Vehicles & 21,421 & 2.3 & 11,265 & 2.6 & 7,219 & 2.0 \\
\hline Financial Assets & 90,926 & 9.9 & 43,811 & 10.2 & 30,922 & 8.6 \\
\hline $\begin{array}{l}\text { Direct Stocks } \\
\text { Holdings }\end{array}$ & 48,983 & 5.3 & 13,720 & 3.2 & 16,640 & 4.6 \\
\hline IRA Assets & 62,296 & 6.8 & 33,551 & 7.8 & 23,291 & 6.5 \\
\hline $\begin{array}{l}\text { IRA in Stocks } \\
\text { Value }\end{array}$ & 45,944 & 5.0 & 22,825 & 5.3 & 17,984 & 5.0 \\
\hline $\begin{array}{l}\text { IRA Plus Stock } \\
\text { Holdings Plus DC in } \\
\text { Stocks }\end{array}$ & 144,401 & 15.7 & 49,388 & 11.5 & 46,927 & 13.1 \\
\hline Observations & 1,657 & & 325 & & 509 & \\
\hline
\end{tabular}

Note: To reduce problems of measurement error, households with top and bottom 1 percent of total wealth are excluded. 
Table 3: Distribution of Assets by Wealth Decile in 2006 For Households with at Least One Member Born from 1948 to 1953

\begin{tabular}{|c|c|c|c|c|c|c|c|c|c|c|}
\hline \multirow{2}{*}{$\begin{array}{l}\text { Sources of } \\
\text { Wealth }\end{array}$} & \multicolumn{10}{|c|}{ Average Asset Value for Respondents in Indicated Total Wealth Deciles } \\
\hline & $1-10$ & $11-20$ & $21-30$ & $31-40$ & $41-50$ & $51-60$ & $61-70$ & $71-80$ & $81-90$ & $91-100$ \\
\hline $\begin{array}{l}\text { Total Wealth } \\
(\$ 000)\end{array}$ & 51.7 & 135.3 & 232.1 & 355.3 & 471.6 & 614.6 & 787.5 & $1,020.3$ & $1,421.4$ & 2,573.9 \\
\hline $\begin{array}{l}\text { (Social } \\
\text { Security } \\
\text { Wealth } \\
\text { +Pension } \\
\text { Wealth)/Total } \\
\text { Wealth (\%) }\end{array}$ & 93.6 & 84.0 & 75.4 & 68.9 & 65.9 & 58.1 & 56.9 & 54.0 & 48.9 & 31.9 \\
\hline $\begin{array}{l}\text { Social } \\
\text { Security } \\
\text { Wealth/Total } \\
\text { Wealth (\%) }\end{array}$ & 89.9 & 78.3 & 65.1 & 53.1 & 47.1 & 35.6 & 31.1 & 26.4 & 19.0 & 11.1 \\
\hline $\begin{array}{l}\text { Total Pension } \\
\text { Wealth/Total } \\
\text { Wealth (\%) }\end{array}$ & 3.7 & 5.8 & 10.3 & 15.8 & 18.9 & 22.5 & 25.8 & 27.7 & 29.9 & 20.8 \\
\hline $\begin{array}{l}\text { DC Pension } \\
\text { Wealth/Total } \\
\text { Wealth (\%) }\end{array}$ & 1.4 & 2.8 & 3.8 & 5.8 & 6.0 & 6.6 & 6.7 & 8.4 & 9.3 & 9.4 \\
\hline $\begin{array}{l}\text { DB Pension } \\
\text { Wealth/Total } \\
\text { Wealth (\%) }\end{array}$ & 2.3 & 3.0 & 6.5 & 10.0 & 12.8 & 15.8 & 19.1 & 19.3 & 20.6 & 11.4 \\
\hline $\begin{array}{l}\text { IRA } \\
\text { Wealth/Total } \\
\text { Wealth (\%) } \\
\end{array}$ & 1.0 & 1.1 & 1.8 & 3.7 & 3.6 & 5.4 & 6.2 & 7.4 & 6.9 & 9.0 \\
\hline $\begin{array}{l}\text { Net Housing } \\
\text { Wealth/Total } \\
\text { Wealth (\%) }\end{array}$ & 5.8 & 9.5 & 17.2 & 18.2 & 20.7 & 23.8 & 23.2 & 22.8 & 23.4 & 22.4 \\
\hline $\begin{array}{l}\text { Wealth Held } \\
\text { Directly in } \\
\text { Stocks /Total } \\
\text { Wealth (\%) }\end{array}$ & 0.2 & 0.2 & 0.5 & 1.4 & 0.6 & 2.4 & 2.3 & 2.7 & 5.4 & 9.6 \\
\hline $\begin{array}{l}\text { Total of } \\
\text { Wealth Held } \\
\text { in Stocks } \\
(\$ 000)\end{array}$ & 0.8 & 3.1 & 9.6 & 26.3 & 33.6 & 67.0 & 84.3 & 130.6 & 227.8 & 580.9 \\
\hline $\begin{array}{l}\text { Total of } \\
\text { Wealth in } \\
\text { Stocks/Total } \\
\text { Wealth (\%) }\end{array}$ & 1.5 & 2.3 & 4.1 & 7.4 & 7.1 & 10.9 & 10.7 & 12.8 & 16.0 & 22.6 \\
\hline
\end{tabular}


Notes: Households with top and bottom 1\% of total wealth are excluded. Values as of 2006 are reported in thousands of dollars. Wealth in stocks includes share of defined contribution accounts in stocks, share of IRA accounts in stocks, and direct stock holdings. 
Table 4: Distributional Effects on Retirement of the Decline in Stock Prices Due to the Dot Com Bust

\begin{tabular}{|c|c|c|c|c|c|c|}
\hline \multirow[b]{3}{*}{ Age in 2000} & \multicolumn{6}{|c|}{ Years of Delayed Retirement } \\
\hline & 0 & 1 & 2 & 3 & 4 & 5 \\
\hline & \multicolumn{6}{|c|}{ Percentage of Simulations (\%) } \\
\hline$\leq 61$ & 77.8 & 15.1 & 5.3 & 1.4 & 0.3 & 0.1 \\
\hline $62-65$ & 86.7 & 11 & 1.7 & 0.3 & 0.2 & 0 \\
\hline$\geq 66$ & 98.6 & 1.3 & 0.1 & 0 & 0 & 0 \\
\hline Overall & 90.4 & 7.3 & 1.8 & 0.4 & 0.1 & 0 \\
\hline
\end{tabular}




\section{Figure 1}

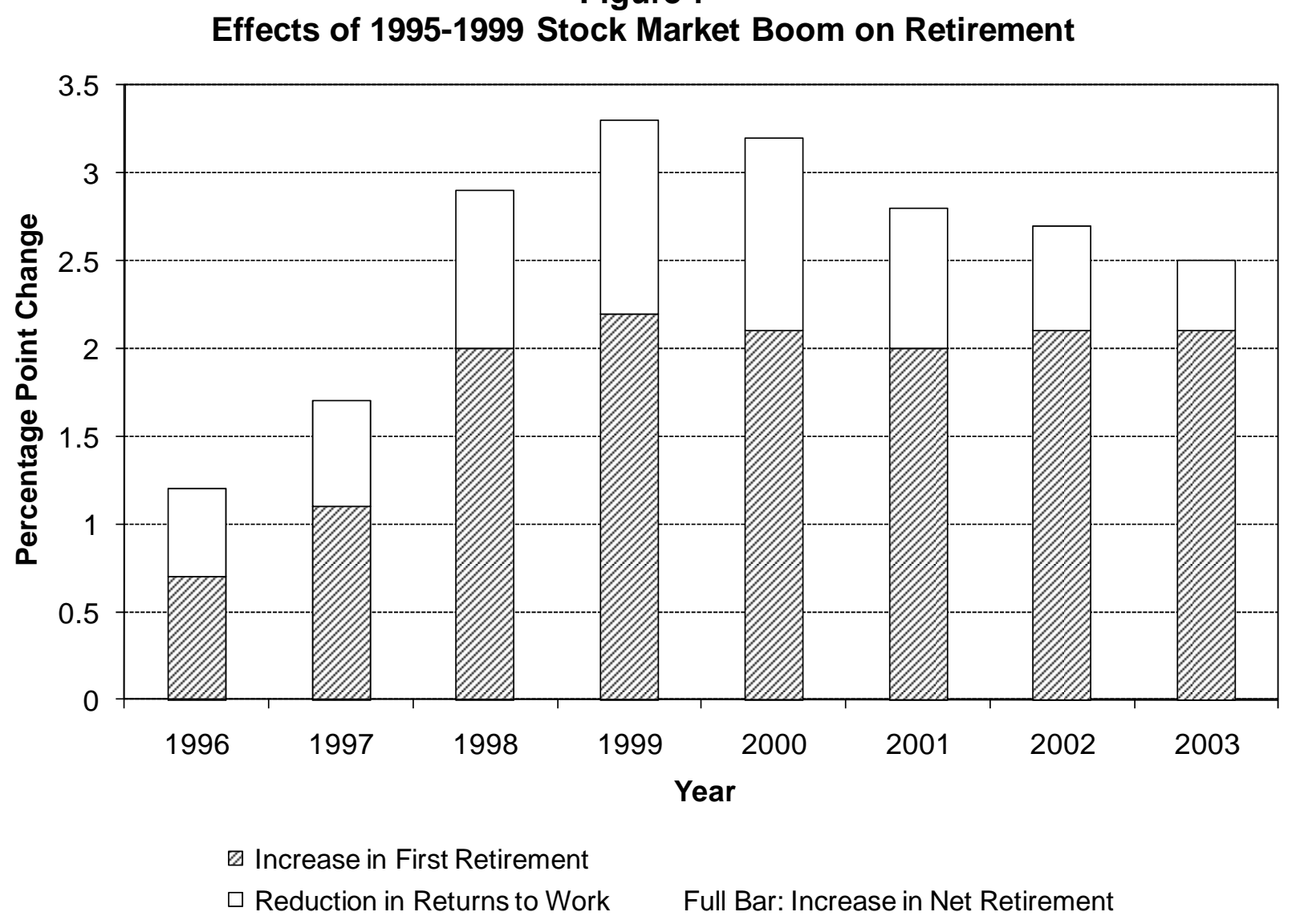

Note: In 1996, 23\% of the sample was 57 years old or younger, 28\% was between 58 and 61 years old, 26\% was between 62 and 65 years old, and 23\% was 66 years old or older. The vertical axis measures the change in percent retired in the specified years. The baseline percentage retired rises from $47 \%$ in 1996 to $63.2 \%$ in 1999 and $82.5 \%$ in 2003. 
Figure 2

Effects of 2000-2002 Stock Market Bust on Retirement

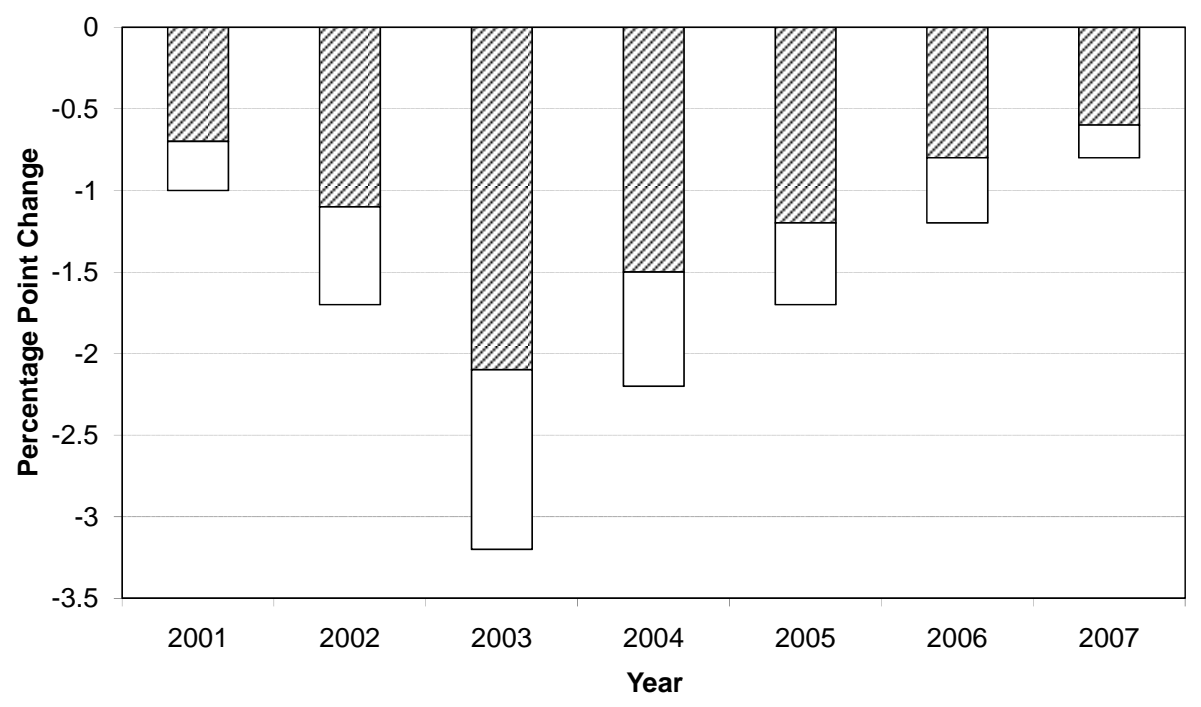

Reduction in First Retirement

$\square$ Increase in Returns to Work Full Bar: Reduction in Net Retirement 
Figure 3. Cumulative Distribution Function of Mortgage to House Value Ratios

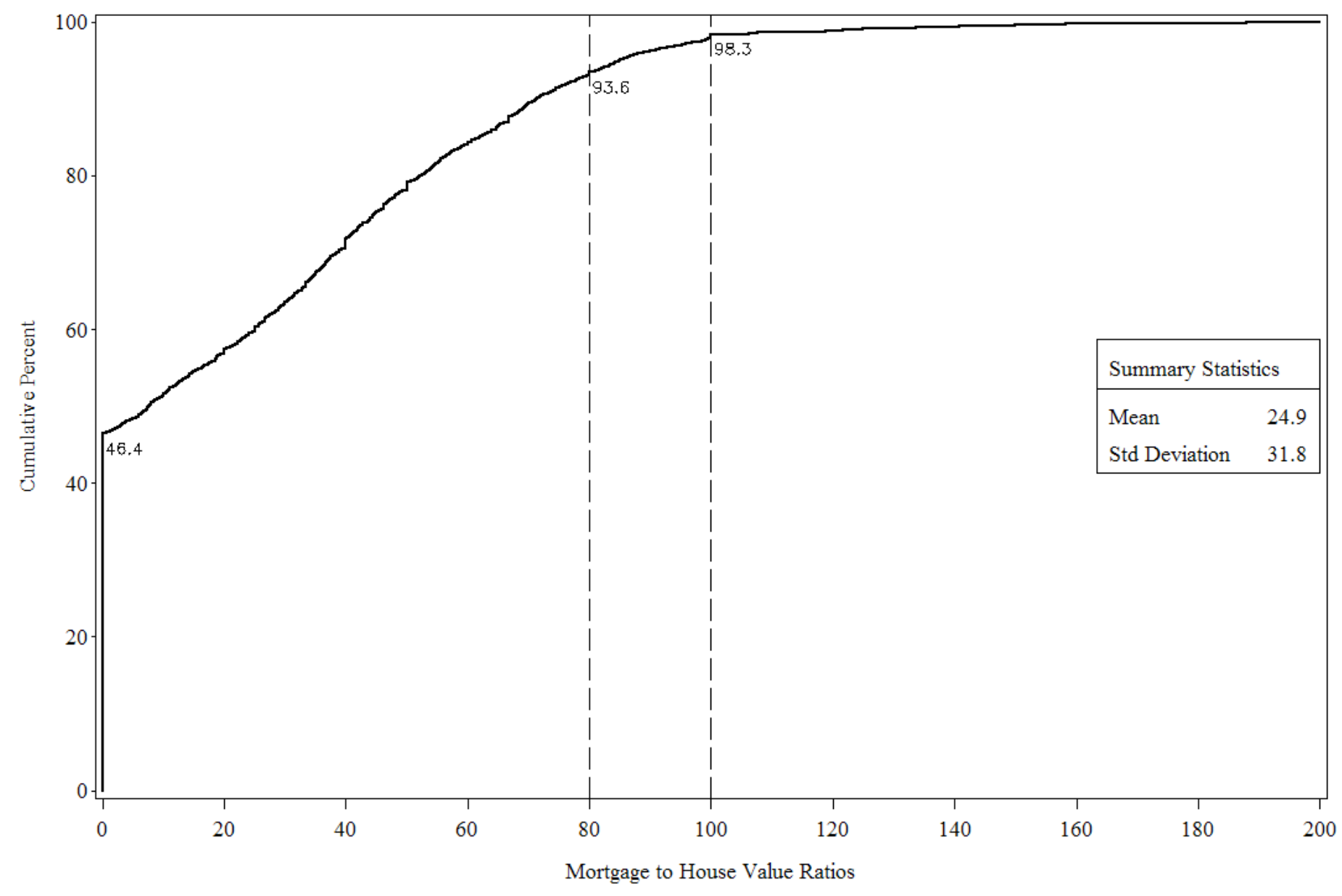

